\title{
What do Old Newspapers Hide?
}

\author{
Ioganson Lidia Ivanovna* \\ Institute of the Physics of the Earth Russian Academy of sciences, Russia
}

*Corresponding author: Ioganson Lidia Ivanovna, Leading Researcher, Schmidt Institute of Physics of the Earth of the Russian Academy of Science, Moscow, Russia.

\author{
Received Date: June 18, 2019 \\ Published Date: June 26, 2019
}

\begin{abstract}
The article is devoted to the informative possibilities of the Russian newspaper "St. Petersburg Vedomosti" for XIII century from point of view of natural disasters. "St. Petersburg Vedomosti" proved to be a valuable source of information for historical seismicity of not only Russia, but also other countries, including Italy. It not only contains the strong Italian earthquakes not recorded in existing catalogs, but from its publications it became possible to identify one of the key seismic activations in Italy relevant to the events 2016-2017. The analysis of seismic regime allows suggesting the long-term seismic sources in the regions of Norcia, Foggia and Irpinia, what deserve the special study. Interesting data are received on the volcanic events of 1751 in the Savoy Alps, which can serve as a warning when assessing the natural risks of this territory. It may suggest that a special type of explosive eruptions may occur in the Alps, though not accompanied by outpourings of lava, nevertheless constituting a great danger.
\end{abstract}

Keywords: Newspaper "St. Petersburg Vedomosti”; XVIII century; Italy; Earthquake; Seismic activation; Savoy; Volcano; Eruption; Landslide

\section{Introduction}

Historical sources for detecting previously unknown earthquakes from chronicles and memoirs to periodicals are widely used to fill the gaps in the existing earthquake catalogs, sufficiently increasing their retrospective series. Such studies have been carried out in many countries and, above all, in Italy, where catalogs of historical earthquakes have begun to be compiled, at least since the 15 th century. So, after some catastrophic earthquakes in the $\mathrm{XV}, \mathrm{XVI}, \mathrm{XVII}$ centuries catalogs from antiquity to the date of the devastating earthquake were compiled here [1]. The most complete corpus of such events was compiled at the turn of the 19th century by geographer Mario Baratta, whose catalog is in demand until today [2]. Research on the replenishment and improvement of the historical catalogs in Italy continues to the present time. Moreover, new and unexpected sources, containing the valuable information about the natural cataclysms of the past are found. Thus, new and of paramount importance information on the subject was recently derived from the Russian newspaper "St. Petersburg Vedomosti" (St. Petersburg journal) of the XVIIIth century. "St. Petersburg Vedomosti" proved to be a valuable source of information for historical seismicity of not only Russia, but also other countries, including Italy. The newspaper regularly published messages about natural disasters, including earthquakes, all over the world. The reports of similar phenomena in Italy were published especially often due to the special seismic activity of this country, and possibly a sufficient number of Russian correspondents here.

Analysis of the Newspaper "St. Petersburg Vedomosti" for Tracing the Seismic Regime in the Central and Southern Apennines

An analysis of the publications of the newspaper "St. Petersburg Vedomosti" (SPV) for the 18th century was carried out by specialists from Institute of Physics of the Earth, RAS (Moscow) and Library of the Academy of Sciences (St. Petersburg) in the framework of the investigation on the project of Russian Foundation for Basic Research "Unusual and extreme events in Nature in society". This work almost contemporized with the tragic consequences of earthquakes in Italy in 2016-2017, which caused large destruction in the cities of Central Italy - Norcia, Amatrice and where earlier, in 2009, the city of L'Aquila was severely damaged. These earthquakes caused great cultural damage and human losses and even provoked the trial of Italian seismologists. An analysis of the newspaper's publications revealed that only for period of 1728-1733 it reports about 26 earthquakes of various forces that occurred in Italy. It is of importance, that some earthquakes were found out which are not included in historical and modern catalogs, among them $[3,4]$, in Puglia (in late February - early March 1732). Perhaps these 
events are not included in the catalogs due to low intensity, but in September and November 1733 in the province of Marche (Ancona) earthquakes occurred with destruction and victims [5,6], which are also not mentioned in the used catalogs. The following catalogs were used in the analysis: The SHARE European Earthquake Catalogue [7-10].

Particular attention in the SPV was paid to strong earthquakes of 1730-1732 in central Italy. They were described in more than ten publications, from which it can be concluded about the place and strength of earthquakes due to the destruction caused by them. These were the earthquakes of May 12, May 27, June 12, 1730 in Norcia, L'Aquila, Sulmona, Lionessa and other closely located points, i.e. in the area affected by the devastating shocks in 2009-2016. On May 12, 1730, a devastating earthquake occurred in Norcia and adjacent areas, and on May 27, the shock repeated here, leading to further destruction and casualties in Norcia. It should be added that modern catalogs have no information about the earthquake of June 12,1730 , during which Leonessa was completely destroyed [1114]. In addition, strong earthquakes were reported on March 20, 1731 in the area of Foggia (Gargano peninsula) and on November 29, 1732 in Irpinia (Neapolitan region) [15]. These areas are located in various parts of the Central and Southern Apennines, which are characterized by the increased seismicity within of the whole seismic active territory of Italy. Each of these 5 seismic shocks had intensity I-IX or more, that is, their totality can be considered as a series of destructive earthquakes concentrated in time, which indicates the seismic activation, involving several dispersed seismic sources within central Italy. On the other hand, the most affected areas by earthquakes in 1730-1732 mostly coincided with the geography of destructive seismic events in Italy in the last period. Thus, compactly placed messages in a newspaper accentuated a specific concentration in time of strong earthquakes in various regions of the country what testified to the seismic activation, involving the several seismic sources.

The coincidence of the geography of the 1730-1732 destructive earthquakes with the events of 2009-2016 has inspired to study the seismic regime of the Central and Southern Apennines from the XIII century, performed for the first time [16]. Recurrence and grouping in time and space of strong earthquakes (I - IX and more) are traced according to historical and modern catalogs. As a result, the eight seismic activations were identified that have appeared from the XV century within Central and Southern Apennines. Thus, general activations involving the Central and Southern Apennine seismic sources, as well as those occurring within only the Central or mainly Southern Apennines, are determined. The detected activations have included from 3 to 7 strong earthquakes and duration from 3 to 20 years (Table 1).

Table 1: Seismic activations in the XV-XXI centuries within Central and Southern Apennines.

\begin{tabular}{|c|c|c|}
\hline \multicolumn{3}{|c|}{ I. Seismic activations of $1456-1466$ (Central and Southern Apennines) } \\
\hline December 5, 1456 & $\mathrm{I}=\mathrm{XI}, \mathrm{M}=7,17$ & Molise \\
\hline November 27,1461 & $\mathrm{I}=\mathrm{X}, \mathrm{M}=6.42$ & Aquillano (L’Aquila) \\
\hline January 15, 1466 & $\mathrm{I}=\mathrm{VIII}-\mathrm{IX}, \mathrm{M}=6.05$ & Irpinia \\
\hline \multicolumn{3}{|c|}{ II. Seismic activations of 1639-1657 (Central Apennines) } \\
\hline October 8,1639 & $\mathrm{I}=\mathrm{X}, \mathrm{M}=6.7$ & Amatrice \\
\hline May 31, 1646 & $\mathrm{I}=\mathrm{X}, \mathrm{M}=6.7$ & Gargano, Foggia \\
\hline July 24,1654 & $\mathrm{I}=\mathrm{X}, \mathrm{M}=6.29$ & $\begin{array}{c}\text { Sorano Marsica (corresponds to the epicentral area of the } 1915 \text { Avezzano } \\
\text { earthquake) }\end{array}$ \\
\hline January 29,1657 & $\mathrm{I}=\mathrm{IX}, \mathrm{M}=6.07$ & Lesina \\
\hline \multicolumn{3}{|c|}{ III. Seismic activation of 1688-1706 (Central and Southern Apennines) } \\
\hline June 5,1688 & $\mathrm{I}=\mathrm{XI}, \mathrm{M}=6.72-6.98$ & Campania, Irpinia, Sannio, Benevento, Campobasso, Avellino \\
\hline September 8, 1694 & $\mathrm{I}=\mathrm{X}, \mathrm{M}=6.79$ & Basilicata \\
\hline March 14, 1702 & $\mathrm{I}=\mathrm{X}, \mathrm{M}=6.5$ & Campania, Irpinia, Benevento \\
\hline April 2 and 6, 1702 & $\mathrm{I}=\mathrm{VIII}-\mathrm{IX}$ & Campania, Apice to East from Benevento \\
\hline January 14,1703 & $\mathrm{I}=\mathrm{XI}, \mathrm{M}=6,73$ & Norcia \\
\hline February 2, 1703 & $\mathrm{I}=\mathrm{IX}, \mathrm{M}=6.2$ & L'Aquilla \\
\hline November 3,1706 & $\mathrm{I}=\mathrm{X}-\mathrm{XI}, \mathrm{M}=6.8$ & Western slope of Maiella massif \\
\hline \multicolumn{3}{|c|}{ IV. Seismic activation of 1730-1732 (Central and Southern Apennines) } \\
\hline May 12,1730 & \multirow{3}{*}{$I=I X, M=5.6$} & \multirow{3}{*}{ Norcia, L'Aquila, Sulmona, Leonessa } \\
\hline May 27,1730 & & \\
\hline June 12,1730 & & \\
\hline March 20, 1731 & $\mathrm{I}=\mathrm{X}, \mathrm{M}=6.1$ & Foggia, Barletta, Cerignole, Canosa, Melfi, San Severo, Andria, Bari \\
\hline November 29,1732 & $\mathrm{I}=\mathrm{X}-\mathrm{XI}, \mathrm{M}=6.63$ & Irpinia, Ariano, Laurino, Napli \\
\hline \multicolumn{3}{|c|}{ V. Seismic activation of 1781-1789 (Central Apennines) } \\
\hline June 3,1781 & $\mathrm{I}=\mathrm{IX}, \mathrm{M}=6.1$ & Cagli \\
\hline
\end{tabular}




\begin{tabular}{|c|c|c|}
\hline October 9,1785 & $\mathrm{I}=9, \mathrm{M}=5.6$ & Piedicullo (west of Leonessa) \\
\hline September 30, 1789 & $I=9, M=5.6$ & Citta di Castello \\
\hline \multicolumn{3}{|c|}{ VI. Seismic activation of 1851-1859 (Central and Southern Apennines) } \\
\hline August 14, 1851 & $\mathrm{I}=\mathrm{X}, \mathrm{M}=6.37$ & Vulture, south from Benevento \\
\hline April 9, 1853 & $\mathrm{I}=9, \mathrm{M}=5.64$ & Caposele Teora, south from Benevento \\
\hline December 16, 1857 & $\mathrm{I}=11, \mathrm{M}=7.1$ & Large area including Potenza, Napli, Bari \\
\hline August 22, 1859 & $\mathrm{I}=\mathrm{VIII}, \mathrm{M}=5.54$ & Norcia \\
\hline \multicolumn{3}{|c|}{ VII. Seismic activation of 1904-1915 (Central and Southern Apennines) } \\
\hline 24-Feb-04 & $\mathrm{I}=\mathrm{IX}, \mathrm{M}=5.7$ & Marsica Rsciolo, north from Avezzano \\
\hline 7-Jun-10 & $\mathrm{I}=\mathrm{IX}, \mathrm{M}=5.8$ & Calitri, south-west from Benevento \\
\hline 13-Jan-15 & $\mathrm{I}=\mathrm{XI}, \mathrm{M}=7$ & Fucino, Avezzano \\
\hline \multicolumn{3}{|c|}{ VIII. Seismic activation of 1997-2017 (Central Apennines) } \\
\hline 26-Sep-97 & $\mathrm{I}=\mathrm{IX}, \mathrm{M}=6,0$ & Colfiorito, Assisi \\
\hline 31-Oct-02 & $M=5.9$ & Puglia \\
\hline 6-Apr-09 & $M=6,3$. & L'Aquila \\
\hline 24-Aug-16 & $\mathrm{I}=\mathrm{VIII}$ & \multirow{3}{*}{ Accumoli, Amatrice, Norcia } \\
\hline \multirow{2}{*}{ October 30, 2016 г. } & $M=6.0$ & \\
\hline & $\mathrm{I}=\mathrm{IX}, \mathrm{M}-6.6$ & \\
\hline January 8, 2017 г. & $M=5.2-5,7$ & Amatrice \\
\hline
\end{tabular}

In addition to the earthquakes listed in the table, earthquakes with I=X in Norcia occurred on December 1, 1328, November 27, 1461, and 9-point earthquakes on April 17, 1747, October 6, 1762, October 9, 1785 and August 22, 1859. Thus, an analysis of the seismic regime has shown that in the region of Norcia-Amatrice L'Aquila-Sulmona-Leonessa more than 10 strong earthquakes were registered in less than 1000 years. Concrete intervals between them vary widely - from 15 to 150 years. These data also allow the suggesting that a large seismic source, manifested in periodic activations of both the entire region of the Central and Southern Apennines and its individual parts is situated in this area. This assumption is in accordance with the established regularities of large seismic sources, representing long-lived structures in the geological environment and occasionally manifested by strong earthquakes [17]. The trigger effect of the Norcia earthquake 1730 on neighboring areas was considered in [18]. Seismic activation of 1639-1657 also began with the Amatrice earthquake. In another work with the participation of the Italian seismologist P. Boncio, it is suggested that seismicity in the Central Apennines is not associated with individual faults, but with "seismogenic volumes" [19]. The existence of a large seismic source, which was manifested by earthquakes in 1997, was also suggested by A.A. Nikonov [20]. Probably, long-lived seismic sources are located also in the areas of Foggia and Irpinia.

\section{The New Vesuvius in Alps?}

Among the reports of SPV, our attention was also attracted by the information on an unusual natural phenomenon in Savoy in July-September 1751, which the locals took for the eruption of a volcano [21-23]. In fact, the mount Plainejou in the province of Fossigny began to erupt the smoke and stones, and then there were flames and sulphuric smell. This continued until September
1751. This event has also been described in a British journal «The London Magazine or Gentlemen's monthly Intelligencer» [24] and German newspaper «Stats- Gelehrte Zeitung Des Hamburgischen unpartheyischen correspondenten» [25].The frightened inhabitants of Savoy, who decided that a new Vesuvius appeared on the site of Mount Plainejou in front of their eyes, turned to Sardinian King Carl Emmanuel III (Savoy then entered the Sardinian kingdom) with request to send a professor from the University of Turin to investigate this phenomenon. Following these reports, an analysis was conducted aimed at clarifying the nature of the Savoy phenomenon, taking into account the generally accepted opinion about the absence of volcanism in the Alps. First of all, a letter was sent to the University of Turin asking to find out who was sent to Savoy for the study of this event and about the results of this study. Professor Clara Silvia Roero, President of the Centro di Studi per la Storia dell'Università di Torino, kindly clarified that this was professor Vitaliano Donati (1717-1762) and, which is more, sent an article on the relevant topic of the Italian colleagues [26]. As follows from this article, Donati had considered the Savoy phenomenon as collapse of the mount Plainejou, due to washing away with underground waters [26]. Over time, afterwards, this event was forgotten and is now regarded as a landslide, though in the work of R. Zornlin "Recreations in Physical Geography or the Earth as it is", 1848, this event is described in the chapter "Volcanic Regions" [27]. However, Donati's conclusions are doubtful, at least for the reason that this event does not correspond to catastrophically rapid collapses in time mount Plainejou has been erupting the smoke and stones for more than a month. In addition, the eyewitness testimonies emphasized its predominantly explosive, but not landslide character. They also witnessed the flame and the smell of sulfur. It is worth to be mentioned, that some references to similar phenomena within Alps, when "the mountains throw out the flame", 
were discovered in other sources [28,29]. From the above materials it can be assumed that very dangerous phenomena can occur in the Alps, which may not be comparable with typical volcanic eruptions, but belong to the same class of explosive manifestations [30].

\section{Conclusion}

In conclusion, it should be noted that the analysis of historical sources in seismological studies is carried out, as a rule, in order to detect unknown earthquakes and, accordingly, to restore a more complete the seismic history of the past. In our case, the "St. Petersburg Vedomosti" newspaper, as a historical source, turned out to be much more informative: it not only contains the strong earthquakes not recorded in existing catalogs, but from its publications it became possible to identify one of the key seismic activations relevant to the events 2016-2017. It should be emphasized, that long-term seismic sources in the regions of Norcia, Foggia and Irpinia deserve the special study. In addition, it seems to be very noteworthy the material on the events of 1751 in the Savoy Alps, which can serve as a warning when assessing the natural risks of this territory.

\section{Acknowledgement}

It is my pleasant duty to express the deep gratitude to the President of the Center for the Study of the History of the University of Turin, Clara Silvia Roero, for kindly provided valuable information that enabled him to restore the history of studying the phenomenon in Savoy in 1751. The work was carried out in the framework of research on the grant of the Russian Foundation for Basic Research No. 17-01-00503.

\section{Conflict of Interest}

There is no conflict of interest.

\section{References}

1. Camassi R (2004) Catalogues of historical earthquakes in Italy. Annals of geophysics 47(2-3): 645-657.

2. Baratta M (1901) I terremoti d'Italia. Saggio di storia geografia e bibliografia sismica italiana. Torino, Italy.

3. SPV, 25.101729

4. SPV, 02.11. 1729

5. SPV, 22.10 .1733

6. SPV, 13.12.1733
7. The SHARE European Earthquake Catalogue (SHEEC) 1000-1899.

8. Van Gils JM, Leydecker G (1991) Catalogue of European earthquakes with intensities higher than 4. Brussels; Luxembourg : Commission of the European Communities - nuclear science and technology, Europe.

9. Geschichte der durch überlieferung nachgewiesenen natürlichen veränderungen der erdoberfläche (1840). In versuch von Hoff Karl Enst Adolf. Gotha, Germany.

10. Mallet R, Mallet JW (1858) The Earthquake Catalogue, London.

11. SPV, 15. 06.1730

12. SPV, 18.06. 1730

13. SPV,06. 07. 1730

14. SPV, 16.07. 1730

15. SPV, 26.04. 1731

16. Ioganson LI (2019) Seismic activations in Italy in the $15^{\text {th }}-21^{\text {st }}$. centuries, from historical data. Seismic instruments 55(2): 209-219.

17. Rogozhin EA, Ioganson LI, Zavialov AD (2011) The potential sources and seismological precursors of the earthquakes. M.: Svetoch Plus, Russia.

18. Boncio P, Lavecchia G, Pace B (2004) Defining a model of 3D seismogenic sources for Seismic Hazard Assessment applications : The case of central Apennines (Italy). Journal of Seismology 8: 407-425.

19. Boncio P, Tinari DP, Lavecchia G, Visini F, Milana G (2009) The instrumental seismicity of the Abruzzo Region in Central Italy (19812003) : seismotectonic implications. Italian Journal of Geosciences 128 (2): 367-380.

20. Nikonov AA (1998) The world masterpices die from earthquakes. Nature (Priroda) 4: 41-44.

21. SPV, 20.09.1751

22. SPV, 1.10 .1751

23. SPV, 10.11. 1751

24. The London Magazine or Gentlemen's monthly Intelligencer XX (1751).

25. Stats- Gelehrte Zeitung Des Hamburgifchen unpartheyifchen correspondenten (1751) Num 150.

26. Scalva G, Caramiello R (2017) Da Torino all'Oceano Indiano, passando per le Alpi. Vitaliano Donati scienziato e viaggiatore, alle origini della scienza moderna. Rivista di Storia dell'Università di Torino 6(2): 83106.

27. Zornlin R (1848) Recreations in Physical geography or the Earth as it is. London.

28. Grishov AT (1794) Consideration on the earthquakes and volcanos . SPb. The new monthly works, parts 91-100.

29. Explanation of the natural reason of the earthquakes (1791).

30. Stats-Gelehrte Zeitung Des Hamburgifchen unpartheyifchen correspondenten. Anno (1751) Num 153. 